\title{
ОСОБЛИВОСТІ ПЕРЕБІГУ БЕШИХИ
}

\section{Особливості перебігу бешихи}

\section{В. П. Борак}

Тернопільський національний медичний університет імені І. Я. Горбачевського МОЗ України

Резюме. Бешиха вважається однією з найбільш неприємних та небезпечних хвороб, яка в більшості викликається бактеріальною інфрекцією та проявляється у вигляді запалення шкірних покривів різної інтенсивності та симптомів ендогенної інтоксикації. Вчасне виявлення захворювання та призначення патогенетично обірунтованого лікування $є$ запорукою успіху в лікуванні даної патології.

Мета дослідження - встановити особливості перебігу сучасної бешихи.

Матеріали і методи. При дослідженні використано дані літературних джерел та опрацьовано 147 історії хвороб з архівних документів. Групи порівняння були зіставними за віком, статтю, за локалізацією запального вогнища, за кратністю захворювання, за тяжкістю перебігу захворювання, сезонністю. У роботі ми дотримувалися клінічної класифрікації бешихи за В. Л. Черкасовим. Отримані дані обробляли на персональних комп'ютерах за допомогою пакета прикладних програм EXCEL-2003.

Результати. Хворих поділили на три групи: з первинною, із рецидивною та повторною бешихою. Серед хворих переважали жінки. Найбільша кількість пацієнтів госпіталізована влітку та весною - 47 хворих, літом 73, восени - 15 і взимку - 12, тобто в літньо-осінньому періоді бешихове запалення розвивається більще, ніж у три-чотири рази частіше (81,6 \%), порівняно із зимово-весняним (18,3 \%). За кратністю захворювання поділ такий: первинна бешиха - 101 (68,7 \%) осіб, значно переважає над іншими фрормами, рецидивна - 30 (20,5\%) і повторна - 16 (10,8 \%). Ступінь тяжкості хвороби у 58,5 \% обстежуваних був середньо-тяжким. Серед клінічних фоорм еритематозну фоору діагностовано у 49,7\% хворих, еритематозно-бульозну -у 24,5\%, еритематозно-геморагічну і бульозно-геморагічну - в 25,8 \%.

Висновки. Бешиха частіше спостерігалася у жінок, мала чітку літньо-осінню сезонність. Реєструється переважно первинна бешихова інфекція, еритематозна форма значно частіше за геморагічні. Перебіг середньої тяжкості превалює над легким і тяжким. Найчастіше запальний процес уражає нижні кінцівки. У клінічній картині вирізняється інтоксикаційний синдром. Ускладнення розвиваються зрідка, причому тільки локальні.

Ключові слова: бешиха; інтоксикація; рецидиви; ступінь тяжкості хвороби; клінічні фрорми.

\section{Features of the course of erysipelas}

\section{P. Borak}

I. Horbachevsky Ternopil National Medical University e-mail: borak@tdmu.edu.ua

Summary. Erysipelas is considered as one of the most dangerous diseases, which in most cases is caused by a bacterial pathogen and manifests itself in the form of inflammation of the skin with varying intensity and symptoms of endogenous intoxication. Early detection of the disease and the prescription of pathogenetically sound treatment the key to success in the treatment of this pathology.

The aim of the study - to establish the features of modern erysipelas.

Materials and Methods. The study used data from literature sources and processed 147 case histories from archival documents. The comparison groups were comparable by age, sex, localization of inflammatory foci, disease multiplicity, disease severity, seasonality. In this work we followed the clinical classification of erysipelas according to V. L. Cherkasov. The obtained data were processed on personal computers by the EXCEL-2003 application package.

Results. Patients were divided into three groups: with primary, with recurrent and repeated erysipelas. Women predominated among the patients. The largest number of patients was hospitalized in summer and spring - 47 patients, in summer - 73, in autumn - 15 and in winter - 12, so in the summer-autumn period erysipelas develops more than three or four times more often (81.6\%) than in winterspring (18.3\%). According to the multiplicity of the disease, the division is as follows: primary erysipelas - 101 (68.7\%), significantly predominates over other forms, recurrent - 30 $(20.5 \%)$ and repeated - 16 (10.8\%). The severity of the disease in $58.5 \%$ of respondents was moderate. Among clinical forms, erythematous form was diagnosed in $49.7 \%$ of patients, erythematous-bullous - in $24.5 \%$, erythematous-hemorrhagic and bullous-hemorrhagic - in $25.8 \%$.

Conclusions. Erysipelas was more common in women, had a clear summer-autumn seasonality. Primary erythema infection is registered mainly, the erythematous form is much more often than hemorrhagic. Moderate to severe prevails over mild and severe. Most often, the inflammatory process affects the lower extremities. The clinical picture is characterized by intoxication syndrome. Complications develop infrequently, and only local.

Key words: erysipelas; intoxication; recurrences; severity of the disease; clinical forms. 


\section{ВСТУп}

Бешиха (рожа, erysipelas) - гостра поверхнева форма запалення клітковини із залученням шкірної та лімсратичної судинної системи, спричинена зараженням стрептококом групи А. $€$ досить частою інфекцією шкіри, яка може зумовлювати значну маніфрестуючу захворюваність у пацієнтів із супутніми станами [4].

Захворювання, зумовлені $\beta$-гемолітичним стрептококом групи А, не втрачають своєї актуальності й продовжують чинити значну соціально-економічну шкоду через широке розповсюдження і наявність несприятливих наслідків.

За даними ВОО3, у країнах світу щорічно реєструється більше 100 млн випадків первинної стрептококової інфекції. Клінічні форми, зумовлені стрептококом, дуже різноманітні: бешиха, скарлатина, ревматизм, ангіна, фрарингіт, піодермія, отит тощо. За даними закордонних авторів, у 72 \% пацієнтів із бешихою етіологічним патогеном $€ \beta$-гемолітичний стрептокок [3, 7]. У рідких випадках ідентифікують патогенні бактерії голкових аспіратів [3-5].

Бешихове запалення $€$ досить поширеним антропонозом. За частотою реєстрації інфекційної патології бешиха займає четверте місце, поступаючись лише гострим респіраторним інсрекціям, вірусним гепатитам та ВІЛ-інфрекції $[1,2]$. На цю інфекцію припадає 15-20 \% усіх запальних захворювань шкіри і підшкірної клітковини .

Проблема мінливості інфекційних хвороб - одна із важливих в інсректології. Це $є$ закономірним процесом, що виникає при взаємодії організму хворого і зовнішнього середовища. Він пов'язаний із безконтрольним застосуванням антибактерійних препаратів, зміною біологічних властивостей збудника, порушення в імунній системі організму людини під впливом природних та соціальних факторів.

$\beta$-гемолітичний стрептокок аплікується на ушкоджену шкіру та слизову оболонку. Умовою виникнення захворювання $є$ попередня сенсибілізація організму стрептококовими антигенами. В подальшому відбувається розмноження стрептококів із виділенням ними акторів патогенності й метаболітів, що викликає при цьому ендогенну інтоксикацію та місцеву запальну реакцію. У зоні розмноження стрептококів виникають набряк, гіперемію, інфрільтрацію тканин, місцеве порушення лімфотоку та кровообігу.

Ушкодження на шкірі внаслідок бешихи, у поєднанні 3 лімфостазом і місцевими порушеннями кровообігу, можуть бути воротами для проникнення іншої бактерійної фрлори з подальшим розвитком місцевих абсцесів, фрлегмон або навіть генералізованого процесу (сепсису). Тому особливого значення набуває не тільки своєчасне розпізнавання цього захворювання, але й адекватне сучасне лікування, що допомагає позбавити хворого від ускладнень і рецидивів.
Метою дослідження було вивчити клінічні особливості бешихи на сучасному етапі.

\section{МАТЕРІАЛИ I МЕТОДИ}

Проаналізовано 147 історій хвороби з архівних документів КНП «Тернопільська міська комунальна лікарня швидкої допомоги». Групи порівняння були зіставними за віком, статтю, за локалізацією запального вогнищ, за кратністю захворювання, за тяжкістю перебігу хвороби, сезонністю. У роботі ми дотримувалися клінічної класифікації бешихи за В. Л. Черкасовим [1]. Отримані дані обробляли на персональних комп'ютерах за допомогою пакетаприкладних програм EXCEL-2003 (Microsoft Corp., США).

\section{РЕЗУЛЬТАТИ Й ОБГОВОРЕННЯ}

За статевою ознакою спостерігається перевага жінок - 58,5 \% над чоловіками - 41,5 \%. Вік пацієнтів коливається в широкому діапазоні від 18 до 75 років, а саме: до 30 років було 6,1 \% хворих, від 30 до $40-8,8 \%$, від 40 до 50 - 46,3\%, від 50 до $60-34,7 \%$, старше $60-4,1 \%$. Спостерігається чітка сезонність: весною - 47 хворих, літом - 73, восени - 15 і взимку - 12, тобто в літньо-осінньому періоді бешихове запалення розвивається більше, ніж у три-чотири рази частіше $(81,6 \%)$ порівняно із зимово-весняним (18,3\%).

За кратністю захворювання поділ такий: первинна бешиха - 101 (68,7 \%) осіб, значно переважає над іншими фрормами, рецидивна - 30 (20,5\%) і повторна - 16 (10,8 \%).

Еритематозну форму діагностовано у 49,7\% хворих, еритематозно-бульозну - в 24,5\%, еритематозно-геморагічну і бульозно-геморагічну - в $25,8 \%$ (рис. 1).

За тяжкістю спостерігається переважно перебіг середньої тяжкості - 86 (58,5 \%) осіб, легкий перебіг - у 13 (8,8 \%) пацієнтів і тяжкий - у 48 (32,7\%) хворих (рис. 2).

За локалізацією запального вогнища спостерігається така картина: 67,3 \% хворих на нижніх кінцівках, у 14,9\% - на обличчі, у 17,7 \% на верхніх кінцівках (рис. 3). Необхідно відмітити, що розвитку

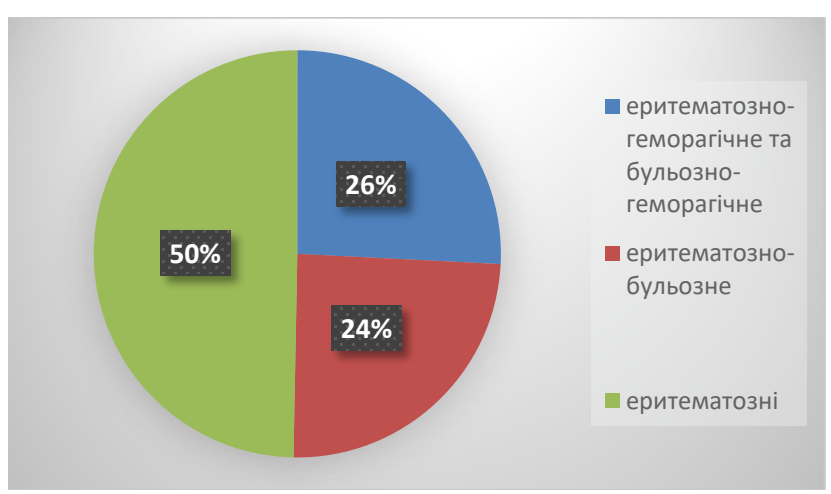

Рис. 1. Співвідношення форм бешихи (\%). 


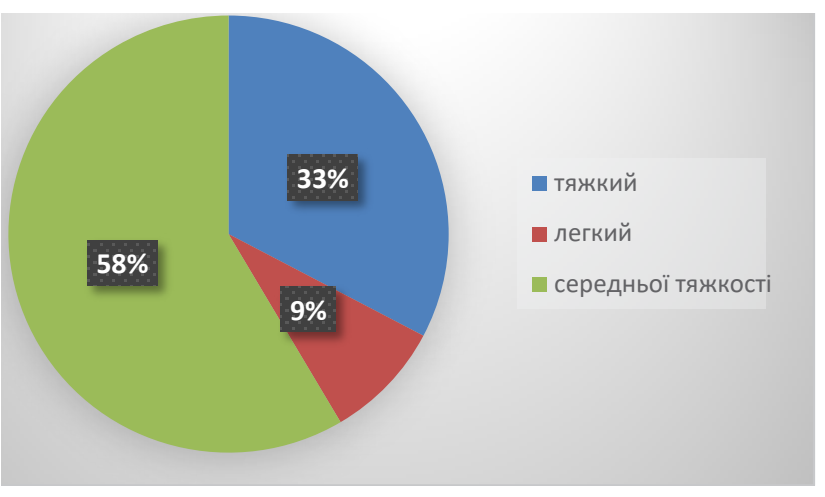

Рис. 2. Поділ хворих за ступенем перебігу (\%).

бешихи на верхніх кінцівках і грудній клітці у жінок передувала мастектомія. У всіх пацієнтів вогнище ураження супроводжується мерзлякуватістю, гарячкою, гіперемією шкіри, набряком м'яких тканин, болем.

При вивченні фракторів, що спричинили розвиток первинної та повторної бешихи, у 38,7 \% хворих встановлено ушкодження шкіри (мікротравми, подряпини, розчухи тощо) та переохолодження. А при рецидивній - міжпальцеву попрілість $(7,4$ \%) мікротравми шкіри (4,7 \%).

При рецидивній бешисі вагоме значення має супровідна патологія. Так, трофрічні виразки -4,08 \%, хронічна венозна недостатність - 9,5 \%, цукровий діабет - 7,4 \%.

Захворюваність на бешиху частіше спостерігається у жінок із локалізацією ураження на нижніх кінцівках через частіше травмування (подряпини, попрілості, тріщини) при фрізичній роботі на городі, у полі з відкритою нижньою третиною гомілки та частішим розвитком фракторів ризику (варикозне розширення вен нижніх кінцівок, лімфостаз, ожиріння, цукровий діабет) [2, 7]. Інколи бешиху важко відмежувати від целюліту, який відноситься до інфекції глибших м'яких тканин, а саме, власне дерми та підшкірної клітковини, або від більш травмувальних станів, таких, як некротизуючий фрасціїт $[5,8]$.

Хвороба починалася гостро з ознобу (94,5%) i підвищення температури тіла до $38-40{ }^{\circ} \mathrm{C}$ і вище (96,5 \%). У 95,2 \% хворих був біль голови, у 49,6 \% біль у м'язах, у 25,1\% - нудота, блювання. Симптоми інтоксикації виникли на добу раніше від місцевих

\section{СПИСОК ЛІТЕРАТУРИ}

1. Ільїна Н. І. Сучасний перебіг бешихи / Н. І. Ільїна, В. В. Захлєбаєва // Інфекційні Інфекційні хвороби в практиці лікаря-інтерніста: сучасні аспекти. - Суми : Сумський держ. мед. ун-т. - 2014. - № 4 (78). - С. 39-42.

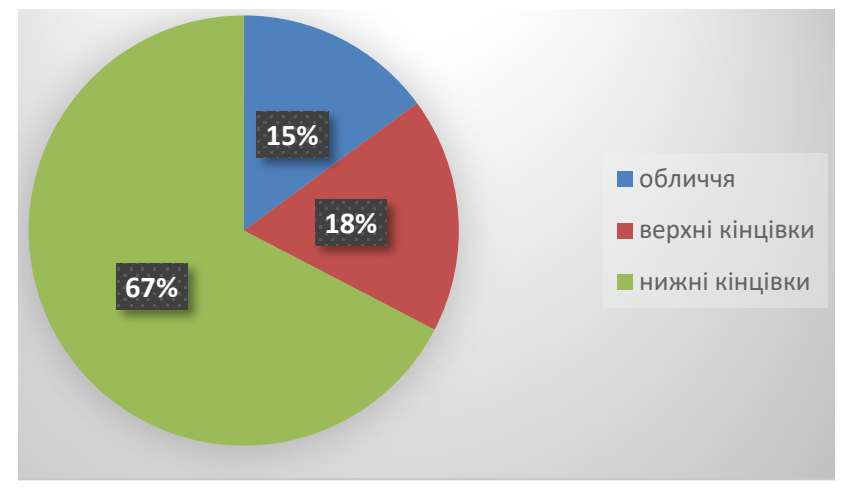

Рис. 3. Поділ топографічної локалізації бешихового вогнища (\%).

запальних уражень у більшості хворих (93,8 \%). Тривалість гарячки при неускладненому перебігу не перевищувала 5-6 діб.

Місцеві прояви запалення зникали значно пізніше нормалізації температури тіла. При еритематозній формі бешихи вогнищеве ураження утримувалося від 5 до 9 діб, при бульозній і геморагічній - до 12-17діб.

Після перенесеного захворювання у 59,8 \% реконвалесцентів відзначено залишкові явища: пігментацію шкіри, вогнищеву застійну гіперемію, щільні кірочки на місці бул, набряковий синдром.

Зміни перифрерійної крові характеризуються помірним лейкоцитозом у 82,9 \% випадків, збільшення шOE - у 95,9\%.

\section{ВИСНОВКИ}

Результати проведеного дослідження дозволяють зробити певні висновки щодо деяких змін перебігу бешихи за останні роки:

- перебіг середньої тяжкості переважає над легким і тяжким;

- найчастіше запальний процес уражає нижні кінцівки;

- бешиха частіше спостерігається у жінок, має чітку літньо-осінню сезонність;

- переважно реєструється первинна бешихова інорекція, еритематозна фрорма значно частіше за геморагічні;

- у клінічній картині вирізняється інтоксикаційний синдром;

- ускладнення розвиваються зрідка, причому тільки локальні.

2. Патоморфологическая и патогистохимическая характеристика рожистой инсекции / В. В. Николов, М. А. Андрейчин, В. С. Копча, Н.А.Васильева // Клінічна імунологія. Алергологія. Інфектологія. - 2015. - № 1. - С. 9-12. 
3. Epidemiology and comorbidity of erysipelas in primary care / S. Bartholomeeusen, J. Vandenbroucke, C. Truyers, F. Buntinx // Dermatol. - 2007. - Vol. 215. - P. 118-122.

4. Druml W. Amino acid kinetics in patients with sepsis / W. Druml, G. Heinzel,

G. Kleinberger // Americal Journal of Clinical Nutrition. 2001. - Vol. 73. - P. 908-913.

5. Goettsch W. G. Burden of illness of bacterialcellulitis and erysipelas of the leg in the Netherlands / W. G. Goettsch, J. N. Bouwes-Bavinck, R. M. C. Herings // J. Eur. Acad. Dermatol. Venereol. - 2006. - Vol. 20. - P. 834-839

\section{REFERENCES}

1. Ilyina $\mathrm{NI}$ Zakhlebaeva VV [Modern course of erysipelas.Infectious Infectious Diseases in the practice of an internist: modern aspects]. Sumy State med un-ty. 2014;4(78): 39-42. Ukrainian.

2. Nikolov VV, Andreichin MA, Kopcha VS, Vasilyeva NA. [Pathomorphological and pathohistochemical characteristics of erysipelas]. Klin imunol alergol infektol. 2015;1: 9-12. Russian.

3. Bartholomeeusen S, Vandenbroucke J, Truyers C, Buntinx F. Epidemiology and comorbidity of erysipelas in primary care. Dermatol. 2007;215: 118-22.

4. Druml W, Heinzel G, Kleinberger G. Amino acid kinetics in patients with sepsis. Amer ical Journal of Clinical Nutrition. 2001;73: 908-13.
6. Hirschmann J. V. Lower limb cellulitis and its mimics: part I. Lower limb cellulitis / J. V. Hirschmann, G. J. Raugi // J. Am. Acad. Dermatol. - 2012. - Vol. 67. - P. 163-175.

7. Vuopio-Varkila J. Factors predisposing to acute and recurrent bacterial non-necrotizing cellulitis in hospitalized patients:Aprospective case-control study/J. Vuopio-Varkila// Clin. Microbiol. Infect. - 2010. - Vol. 16. - P. 729-734

8. Acute bacterial, nonnecrotizing cellulitis in Finland: microbiological findings / T. Siljander, M. Karppelin, S. Vahakuopus [et al.] // Clin. Infect. Dis. - 2008. - Vol. 46. - P. 855-861.

5. Goettsch WG, Bouwes-Bavinck JN, Herings RMC. Burden of illness of bacterialcellulitis and erysipelas of the leg in the Netherlands. J Eur Acad Dermatol Venereol. 2006;20: 834-9.

6. Hirschmann JV, Raugi GJ. Lower limb cellulitis and its mimics: part I. Lower limb cellulitis. J Am Acad Dermatol. 2012;67: 163-75.

7. Vuopio-Varkila J. Factors predisposing to acute and recurrent bacterial non-necrotizing cellulitis in hospitalized patients: a prospective case-control study. Clin Microbiol Infect. 2010;16: 729-34.

8. Siljander T, Karppelin M, Vahakuopus S. Acute bacterial, nonnecrotizing cellulitis in Finland: microbiological findings. Clin Infect Dis. 2008;46: 855-61. 